\title{
Assessing the ecological sustainability of a forest management system using the ISO Bowtie Risk Management Assessment Tool
}

\author{
by B.E. Kishchuk ${ }^{1 *}$, I.F. Creed ${ }^{2}$, K.L. Laurent ${ }^{2}$, S. Nebel², D. Kreutzweiser ${ }^{3}$, L. Venier ${ }^{3}$ and K. Webster ${ }^{3}$
}

\begin{abstract}
The boreal zone is at risk of cumulative effects of natural resource extraction activities, which may be further exacerbated in the face of climate change. A major challenge is the lack of common approaches to assess the effectiveness of management measures (e.g., acts, regulations, standards, guidelines, best management practices and certification systems) to determine if the policy objective of sustainable management of the boreal zone is being met. The International Organization of Standardization (ISO) 31000 Risk Management Standard and ISO 31010 Bowtie Risk Management Assessment Tool provide a recognized and credible approach for analyzing risk of policy failure, by articulating: (1) the "risk pathway", linking the pressures, effects and impacts based on science; (2) the performance of the system of management measures in reducing risk; and, (3) the interactive nature of management measures in the presence of escalating factors, including climate change. Here we present the first application of the Bowtie tool in terrestrial ecosystem management by examining forest management pressures and impacts on water quality and biodiversity. We provide a policy analysis tool with potential for addressing risks associated with the future sustainability of the boreal zone.
\end{abstract}

Keywords: ISO 31000, ISO 31010, risk management, boreal zone, forest management, cumulative effects

\begin{abstract}
RÉSUMÉ
La zone boréale risque de subir de l'effet cumulatif des activités de prélèvement de ressources naturelles qui pourrait s’aggraver dans un contexte de changements climatiques. Notre principal handicap est labsence d'approche commune pour évaluer l'efficacité des activités d’aménagement (par ex., lois, règlements, normes, directives, saines pratiques de gestion et systèmes de certification) pour établir si lon atteint lobjectif fixé dans la politique d’aménagement de la zone boréale. La norme ISO 31000 Management du risque et loutil dévaluation ISO 31010 Bowtie Risk Management Assessment Tool de l'Organisation internationale de normalisation (ISO) offrent une approche reconnue et crédible pour analyser le risque d'échec d'une politique explicitant (1) le « diagramme de risque », les pressions, les effets et les impacts sur des bases scientifiques; (2) lefficacité du système d’aménagement à diminuer le risque; et (3) la nature interactive des techniques d’aménagement en présence de facteurs d’aggravation, dont les changements climatiques. Dans cet article, nous présentons les résultats de la toute première application de la méthode Bowtie à la gestion des écosystèmes terrestres en examinant les pressions exercées par l’aménagement forestier et ses impacts sur la qualité de l'eau et la biodiversité. Nous proposons ainsi un outil d’analyse des politiques qui permettra dévaluer les risques liés à lavenir de la durabilité dans la zone boréale.
\end{abstract}

Mots-clés : ISO 31000, ISO 31010, gestion du risque, zone boréale, aménagement forestier, effets cumulatifs

\section{Introduction}

The Canadian Forest Service-Natural Resources Canada (CFS) has taken a lead in the use of ISO 31000 Risk Management Standard to assess the cumulative effects of natural resource development in the boreal zone. A comprehensive review of the risks related to natural resource extraction activities and climate change to the boreal zone was completed and published in a series of synthesis papers (Kreutzweiser et al. 2013; Kurz et al. 2013; Lemprière et al. 2013; Price et al. 2013; Andrew et al. 2014; Gauthier et al. 2014; Langor et al. 2014; Maynard et al. 2014; Venier et al. 2014; Webster et al. 2015). The main conclusion of the synthesis papers was that cumulative effects of natural resource development under a chang- ing climate are creating increased uncertainties and potentially heightened risks to sustainability in the boreal zone.

A nationally applicable framework for assessing cumulative effects and their policy implications has not, to date, been developed for Canada (Canadian Council of Ministers of the Environment 2009). We lack cumulative effects assessments explicitly integrating both science and management. The Canadian Forest Service is exploring alternative risk management frameworks, including the risk management framework developed by the International Organization for Standardization (ISO), in response to the need for a broadly applicable and science-based approach to cumulative effects assessment that integrates science and management.

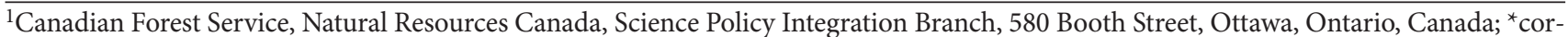
responding author's email: barbara.kishchuk@canada.ca

${ }^{2}$ Department of Biology, Western University, London, Ontario, Canada

${ }^{3}$ Canadian Forest Service, Natural Resources Canada, Great Lakes Forestry Centre, Sault Ste. Marie, Ontario, Canada
} 
The ISO 31000 Risk Management Standard (ISO 2009) has been applied to evaluate the cumulative effects of a system of management measures within an aquatic ecosystem context (Cormier et al. 2013). Within this standard, the ISO 31010 Bowtie Risk Management Assessment Tool (IEC/ISO 2009) has been used to identify gaps and redundancies in the system of management measures and evaluate the overall performance of the system in relation to policy objectives related to aquatic ecosystems (Creed et al. 2016a). The Bowtie assembles and analyzes the management system framework, creating a means to assess the effectiveness of prevention and mitigation management measures and the degree of compliance with those measures across a range of regulations, guidelines, and best practices pertaining to ecosystem management (e.g., Stelzenmüller et al. 2018).

Until now the Bowtie tool has not been applied to terrestrial ecosystems, based on review of publically available information. We explored the utility of the Bowtie tool in supporting decisions to reduce risk to sustainable forest management, defined as "management that maintains and enhances the long-term health of the forest ecosystem for the benefits of all living things while providing environmental, economic, social and cultural opportunities for present and future generations" (Canadian Council of Forest Ministers 2008). Sustainable forest management aims to simultaneously uphold forest ecosystem integrity and maintain or enhance Canada's domestic and international environmental reputation while providing environmental, economic, social and cultural opportunities from the forest. There are established criteria to track progress in achieving sustainable forest management at international and national levels (Montréal Process 2015; Canadian Council of Forest Ministers 2008, respectively).

In this paper, our objectives are: (1) to inventory the existing legislated (i.e., Acts, regulations, standards, guidelines) and non-legislated (i.e., best management practices (BMPs) and forest certification standards) frameworks designed to reduce risk of failing to achieve sustainable forests; and, (2) to implement the Bowtie approach for mapping management systems to determine if they are sufficiently rigorous to achieve sustainable forest management. We focus on the forest management systems in place for provision of clean and reliable water supplies and aquatic habitats, and support of biodiversity for two Forest Management Units in northern Ontario. By applying an internationally recognized ISO-certified framework, there will be a high degree of credibility for our assessment of the completeness and strength of the existing forest management system, and a platform for further analysis of its effectiveness.

\section{Policy Issue}

Failure to achieve sustainable forest management places the ecological integrity of the boreal zone at risk, and jeopardizes the competitiveness, international reputation and therefore economic success of Canada's forest sector. Concern is emerging that, despite the presence and implementation of legislated and non-legislated controls, forest management in the Canadian boreal zone may not be sustainable (e.g., Brandt et al. 2013). These concerns have the potential to contribute to an adverse environmental reputation (e.g., Moas 2014; Char- trand 2016; Kuitenbrouwer and Thompson 2016), which in turn may lead to decreased market access for forest products, including solid wood, pulp and paper, and engineered wood products (Canadian Council of Forest Ministers 2017).

\section{Legislated controls}

In 1992, the Canadian Council of Forest Ministers and the forest sector more broadly endorsed national adoption of Sustainable Forest Management principles (Canadian Council of Forest Ministers 2008; Natural Resources Canada 2016). Canada reports its progress on Sustainable Forest Management annually in the State of Canada's Forest Report (e.g., Natural Resources Canada 2017) using six criteria and 19 indicators, based on the National Criteria and Indicators Framework (Canadian Forest Service 2005). This National Framework consists of six criteria (biological diversity; ecosystem conditions and productivity; soil and water; role in global ecological cycles; economic and social benefits; and society's responsibilities) and 46 indicators (Canadian Forest Service 2005).

\section{Non-legislated controls}

In addition to the legislated forest management activities implemented by provincial and territorial governments, some forest companies use non-legislated measures such as forest certification (e.g., Clark and Kozar 2011). While forest certification is not obligatory, it has become an important means of securing and maintaining domestic and international market access by demonstrating sustainable forest management practices (Moore et al. 2012; Rotherham 2016). Forest certification systems currently used in Canada are the Sustainable Forestry Initiative (SFI; Sustainable Forestry Initiative 2015), Forest Stewardship Council Canada (FSC; Forest Stewardship Council Canada 2016), and Canadian Standards Association Sustainable Forest Management (CSA; Canadian Standards Group 2016). As of 2016, SFI, FSC, and CSA have 89, 54, and 42 million ha certified, respectively (Certification Canada 2017). In addition, some forest companies in Canada are also registered with the broader ISO 14001 Environmental Management System standard, entailing certification and associated requirements such as best practices and monitoring (International Organization for Standardization 2015). Over 185 million ha of forests in Canada are certified (Certification Canada 2017). This means that many companies are meeting forest certification standards as well as all legislated requirements.

\section{Methods \\ ISO 31000 and 31010}

The ISO 31000 Risk Management Standard (Fig. 1) is used to evaluate the risk of not achieving policy objectives. ISO 31000 consists of the following five steps:

Step 1 is to define the management context and the policy objective. Step 2 is to identify risks resulting from not achieving the policy objective. Step 3 is to analyze risks by looking at the effectiveness and compliance of the system of management measures to reduce pressures and impacts. The ISO 31010 Bowtie Risk Management Assessment Tool (Fig. 2) facilitates Step 3 by providing a framework for structured analysis of the 


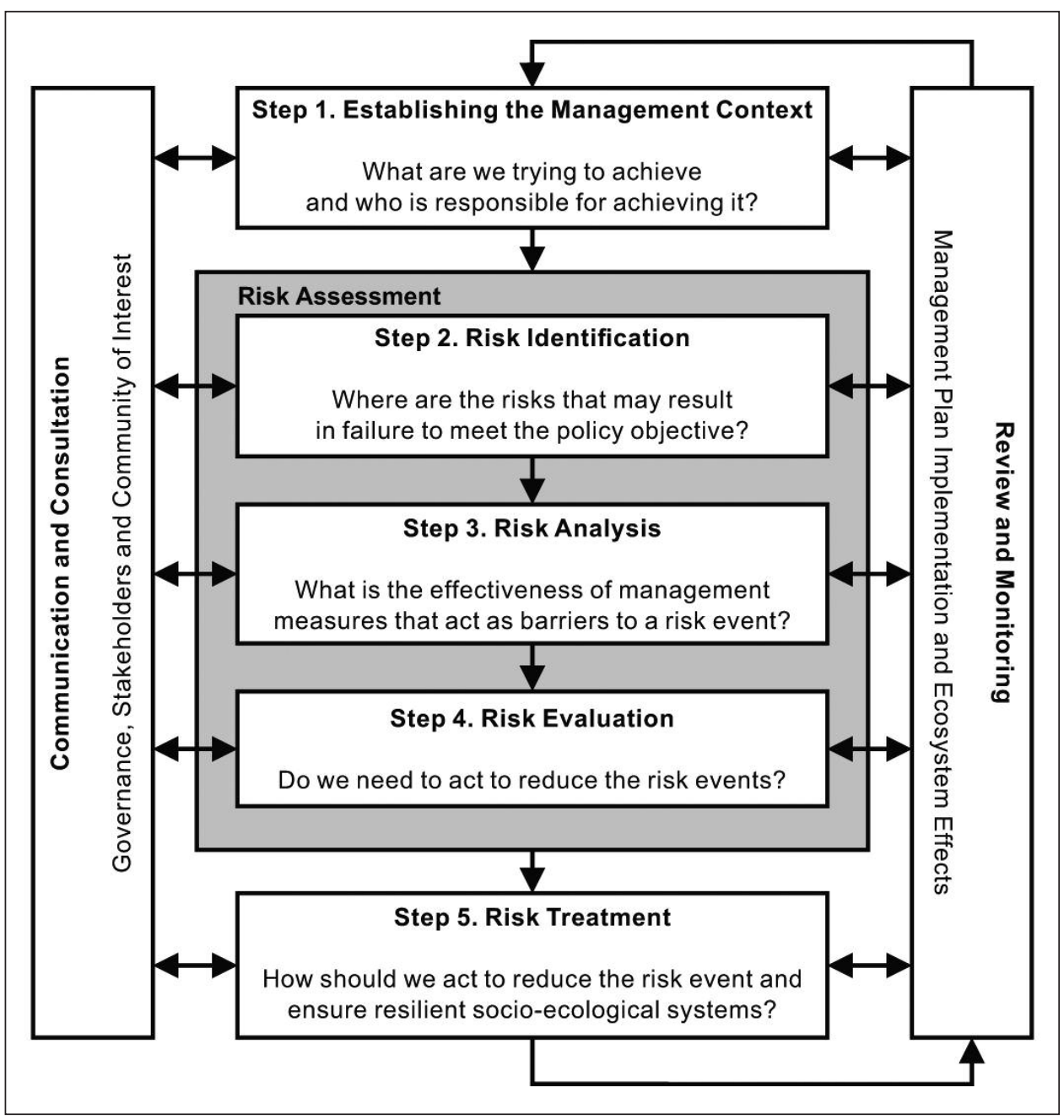

Fig. 1. Schematic diagram of the five steps of the ISO 31000 Risk Management Standard (Creed et al. 2016a)

system of management measures. At the centre of the Bowtie (i.e., the "knot") is the risk event of policy failure (or an undesirable outcome). From the left to the right of the risk event are pressure-effect-impact pathways, with an increase in pressures leading to an increase in the likelihood of the risk event taking place, and the increase in effects leading to an increase in the likelihood of impacts. To the far left, drivers are the human activities that contribute to the pressures and to the far right, consequences are adverse implications for society because of the impacts. Along the pressure-effect-impact pathways are management measures that can be put in place to prevent the risk event from occurring or to mitigate its effects if it does occur, as well as external factors (e.g., climate change) that may undermine the effectiveness of the management measures (CGE Risk 2015). The relative emphasis between the "preventative" left-hand side compared to the "mitigative" right-hand side may reveal the strength of the legislated and non-legislated framework in place for prevention, avoidance, and mitigation of threats to sustainable forest management. Step 4 is risk evaluation to decide if the risk is tolerable or if changes to the system of management measures are necessary to meet societal demands. Finally, if risk is not tolerable, Step 5 is to implement changes to the system of management measures and thereby reduce the risk of not achieving the policy objective (Creed et al. 2016a, b).

In this paper, we addressed Step 1 by establishing the context for sustainable forest management in the Ontario boreal zone. We addressed Step 2 by identifying the risk of not achieving sustainable forest management. We addressed Step 3 by considering pressures and associated management measures that reduce effects and impacts for sustainable forest management. We considered the distribution of management measures by jurisdiction (federal, provincial), or as certification. Steps 4 and 5 were beyond the scope of this paper.

\section{Pressures-effects-impacts pathways}

Our analyses focused on two attributes central to the Sustainable Forest Management criteria: water quality and biodiversity. The pressureseffects-impacts pathways were based on risks identified in the boreal synthesis reviews (e.g., Kreutzweiser et al. 2013; Venier et al. 2014; Webster et al. 2015), published guides and reviews (e.g., Ontario Ministry of Natural Resources 2010, 2014a; Ontario Ministry of Natural Resources and Forestry 2015; National Council for Air and Stream Improvement 2014).

Pressures that may influence water quality are forest removal, wetland damage or removal and other wet soil disturbances, road construction, riparian forest removal, watercourse crossings, pesticide applications, fuel storage and handling, and operational waste. These pressures may lead to the impacts of reduced surface water quality, changes to energy and nutrient cycling, reduced water clarity, and unwanted changes in microbial activity, and aquatic species abundance (Kreutzweiser et al. 2013; Webster et al. 2015).

Pressures that may influence biodiversity are change in forest tree species composition, age class distribution, landscape composition, forest structure, forest fragmentation, forest loss, wetland disturbance, road construction, forest floor disturbance, and introduction of invasive species. These pres- 


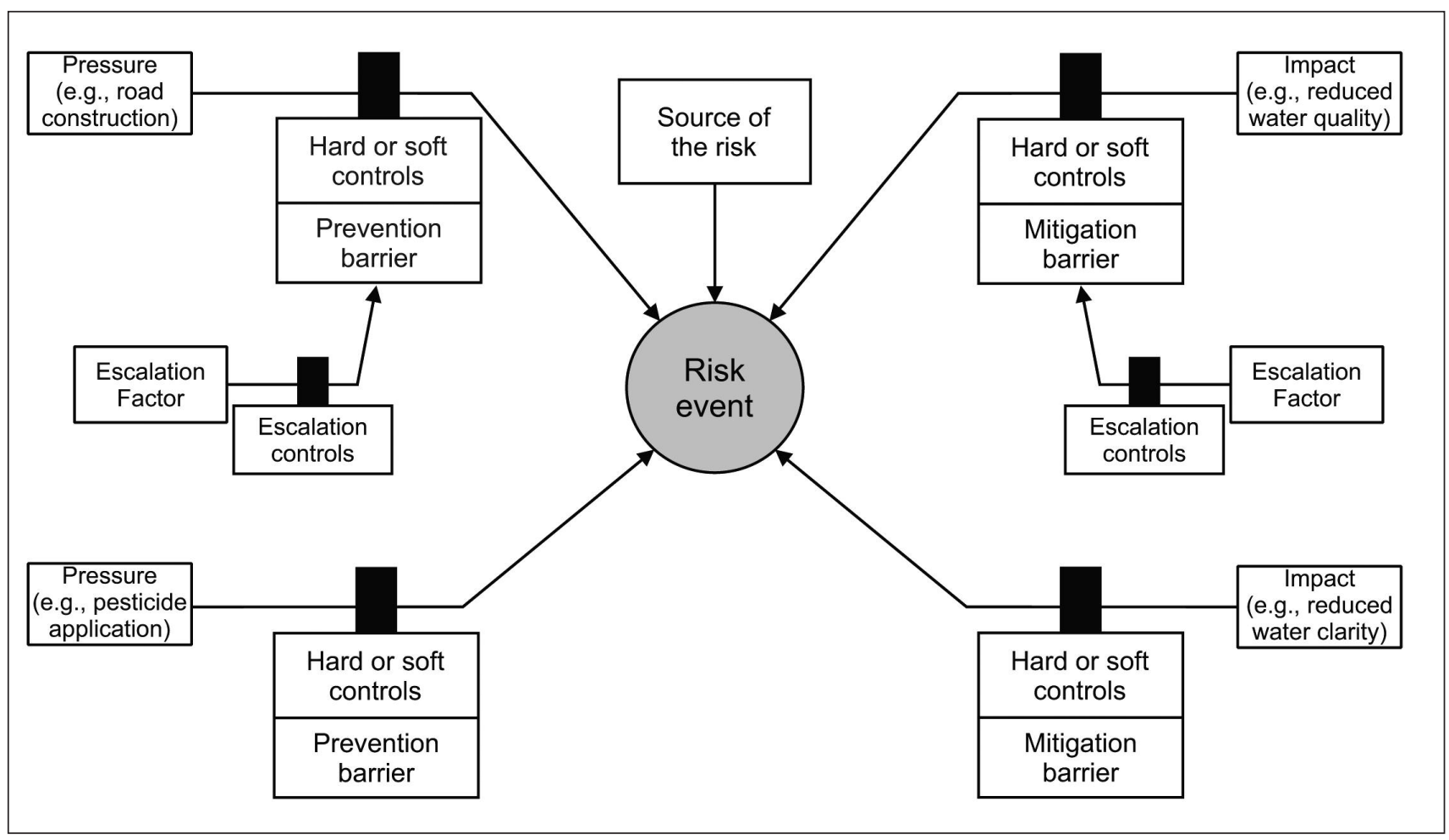

Fig. 2. Conceptual diagram of the BowtieXP's output for the ISO 31010 Bowtie Risk Management Assessment Tool. Far left are pressures. Between pressures and risk event are preventative measures. Far right are impacts. Between risk event and impacts are mitigative measures.

sures may lead to changes in timber supply, changes to downstream energy and nutrient cycling, decreased decomposition, changes in forest productivity, or species loss (habitat reduction) (Venier et al. 2014).

\section{Management measures}

We assessed the system of management measures for two Forest Management Units (FMUs) in northern Ontario, for which sustainable forest management is an essential policy driver under the Crown Forest Sustainability Act (Ontario Ministry of Natural Resources 1994).

We considered both legislated and non-legislated components of the management system. Forest management plans are required for the FMUs, and tenure holders for the FMUs considered here also participate in one or more forest certification systems. The legislated measures comprised Acts, regulations, standards, and guidelines that apply to forest operations (Ontario Ministry of Natural Resources 2010, 2014a; Ontario Ministry of Natural Resources and Forestry 2015; National Council for Air and Stream Improvement 2014). The non-legislated measures comprised BMPs and forest certification standards (Sustainable Forestry Initiative 2015; Forest Stewardship Council Canada 2016) applied on these FMUs.

We also considered both structural (Act, regulation, standard, guideline, BMP, certification standard) and functional (avoid, prevent, mitigate, enable, facilitate, track) components of the system of management measures (Creed et al. 2016a). As no precedent existed for classification of functional components of the system of forest management measures, our clas- sification was determined by interpretation of each measure's intention. For example, measures related to appropriate practices in construction of roads or water crossings were classified as intending to avoid or prevent loss of water quality.

We created Bowtie diagrams using BowtieXP software (Release Version 8.2.9 2017; CGE Risk Management Solutions). A schematic of the BowtieXP software output is shown in Fig. 2. The first Bowtie inventoried the management measures obtained from the above sources as individual pieces of direction for each of the potential pressures and impacts. The hierarchical nature of the management measures prevented complete avoidance of overlap among some measures. A decision for "best fit" to minimize overlap was made on a case-by-case basis. The second Bowtie characterized the structure of the management system. The third Bowtie characterized the function of the management system. When populated with information, Bowtie diagrams are often not easily readable in their original format, and we have therefore synthesized the information contained in the original Bowtie diagrams into more visually clear summary diagrams in Fig. 3 (water) and Fig. 4 (biodiversity). This was done by enumerating the number of management measures and converting the numbers to percentages.

The Bowties are based on the inventory of pressures and impacts listed in Supplementary Information 1 (water) and 2 (biodiversity), as well as the legislated and non-legislated measures to reduce the risks associated with these pressures and impacts listed in Supplementary Information 3 (water) and $\mathbf{4}$ (biodiversity). 
a

Pressures

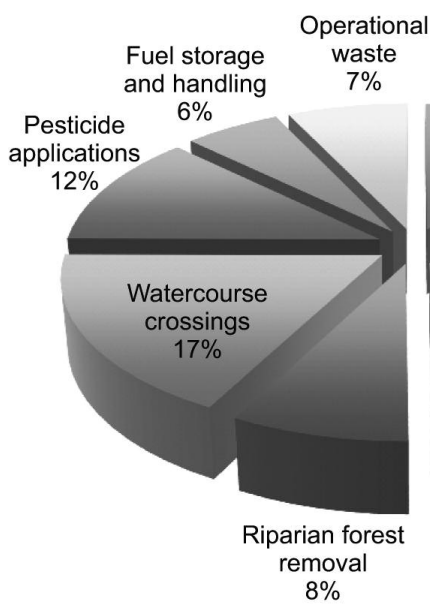

b

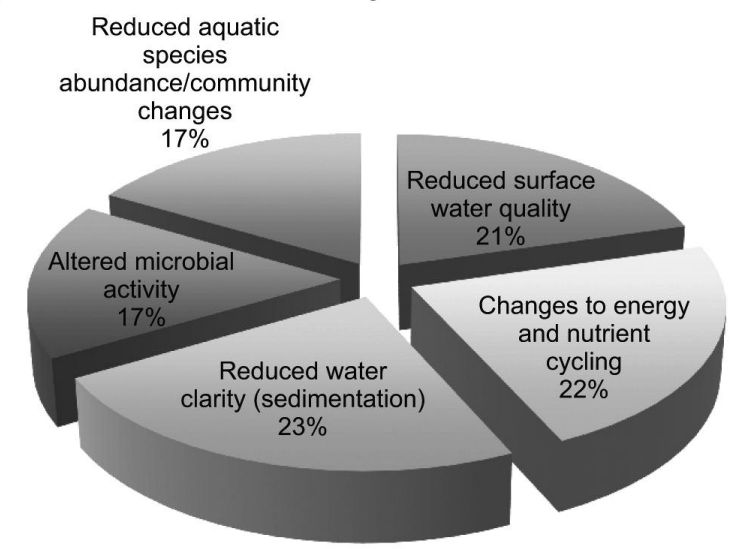

c Prevention of effect

Mitigation of effect

Structure

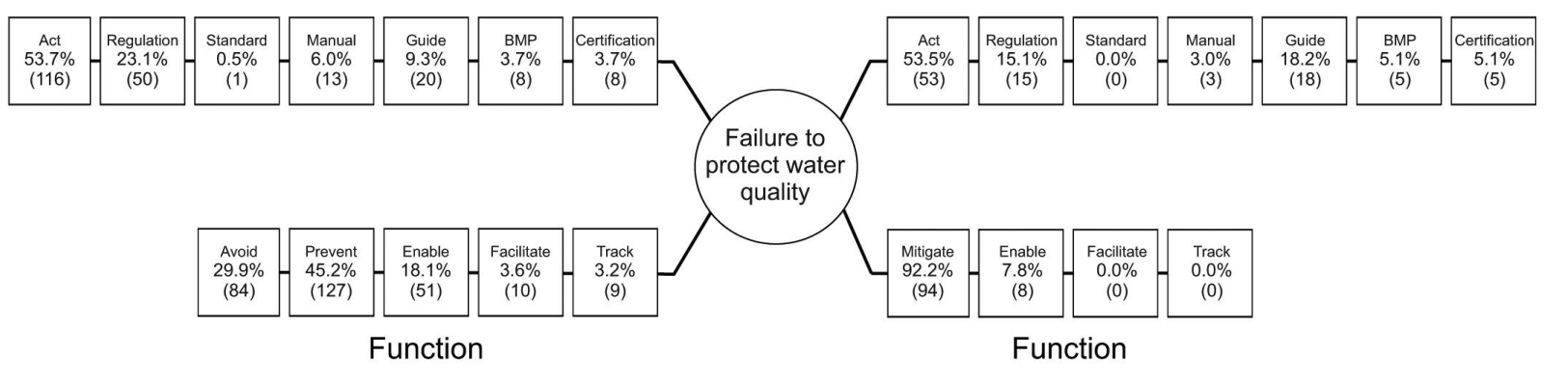

Fig. 3. For the risk event "failure to protect water quality", a categorization of pressures (a) vs. impacts (b), and a breakdown of preventative vs. mitigative measures and structural vs. functional measures by both proportion (\%) and absolute numbers [in (J] for these pressures and impacts (c).

\section{Results}

\section{Water quality Bowtie}

Of the 315 management measures for protection of water resources, nearly $70 \%$ (216) are directed toward prevention. Within preventative measures, $44 \%$ are focused on reducing direct pressures on water features (Fig. 4a). These include measures to avoid wetland removal/drainage and other wet soil disturbances (27\%) and watercourse crossings (17\%). Reductions of indirect pressures on water features are focused on restricting forest removal and maintaining riparian buffers (19\%) and on careful road construction (12\%). The remaining $25 \%$ of measures are focused on other indirect pressures related to pesticide applications and proper handling of fuel and operational wastes. Within mitigative measures, $34 \%$ are focused on reducing impacts on aquatic biodiversity and its activity, $44 \%$ to reducing impacts on physiochemical properties such as water quality and turbidity, and $22 \%$ are related to reducing impacts on nutrient cycling (Fig. 4b).

Most of the preventative (77\%) and mitigative (97\%) measures are legislated (Fig. 4c). The mitigative measures are not necessarily designed to respond to observed impacts on water quality, rather they are designed to minimize potential impacts on water quality after forest harvesting operations are completed, such as the careful decommissioning of roads to prevent subsequent erosion and sedimentation in water bodies.

Most (75\%) of the preventative measures are hard controls of prevent (45\%) and avoid (30\%) actions, whereas $25 \%$ are soft controls enabling (18\%), facilitating (4\%), and tracking (3\%) the hard controls. Most (92\%) of the mitigative measures are hard controls.

The hierarchical structure of the system of management systems from Acts to BMPs makes a clear distinction among these structural elements somewhat arbitrary. Nevertheless, for preventative measures, Acts and regulations accounted for $77 \%$ of the total water-related measures, with the remaining $23 \%$ comprised of guides, manuals, standards BMPs and other certification requirements. For mitigative measures, Acts and regulations accounted for $69 \%$ of the total waterrelated measures, with the remaining 31\% comprised of guides, manuals, BMP's, standards, and certification.

By jurisdictional level, 26\% of the preventative measures for water quality are at the federal level, $66 \%$ are at the provin- 
a

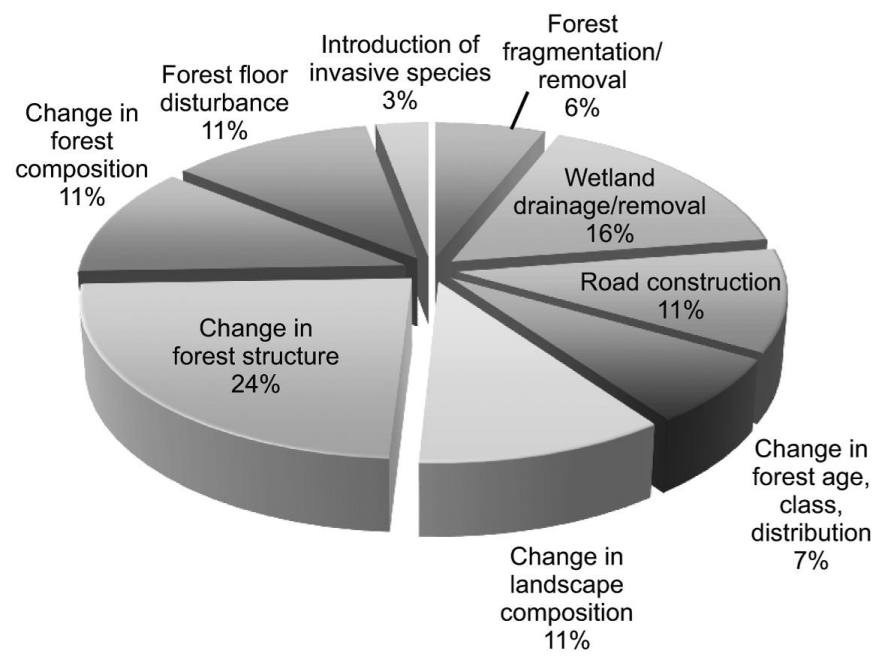

c Prevention of effect b

\section{Impacts}

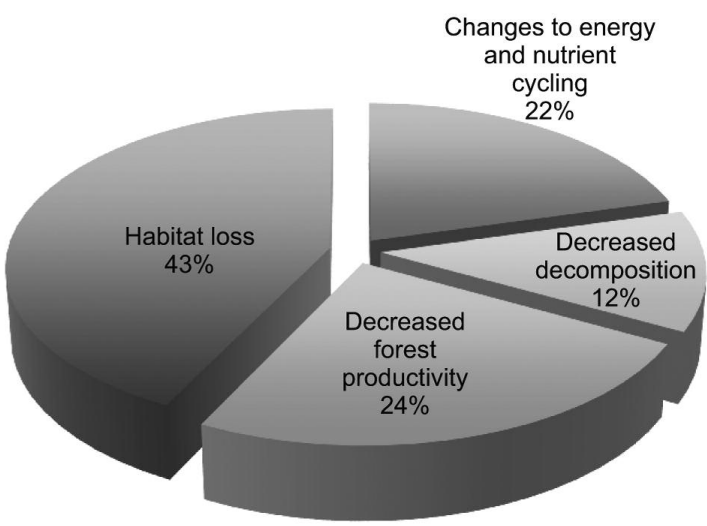

Mitigation of effect

Structure

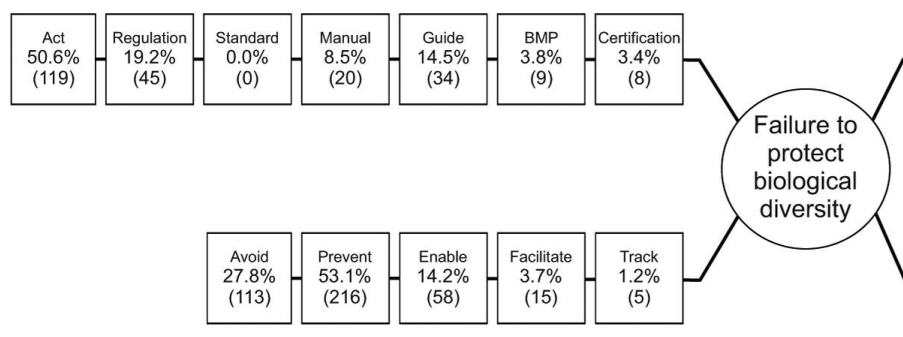

Function

Structure

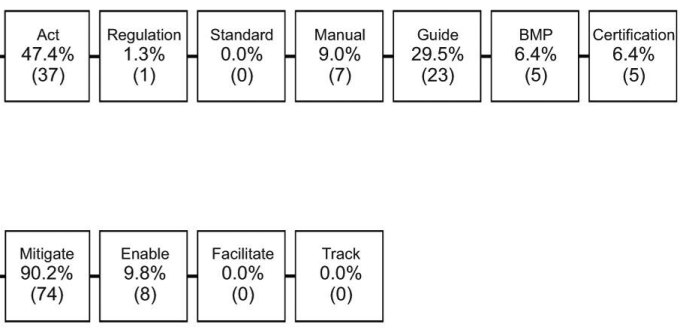

Function

Fig. 4. For the risk event "failure to protect biodiversity", a categorization of pressures (a) vs. impacts (b), and a breakdown of preventative vs mitigative measures and structural vs. functional measures by both proportion (\%) and absolute numbers [in ()] for these pressures and impacts (c).

cial level, and $7 \%$ are from certification. By jurisdictional level, $6 \%$ of the mitigative measures are at the federal level, $82 \%$ are at the provincial level, and $12 \%$ are from forest certification. Of the non-legislated measures for water quality, $77 \%$ percent are from provincial sources (e.g., BMPs) and $23 \%$ are from certification sources.

\section{Biodiversity Bowtie}

Of the total of 313 management measures for protection of biodiversity, nearly $75 \%$ (235) are directed toward prevention. Within preventive measures, $53 \%$ are focused on reducing pressures on the forest attributes (e.g., forest composition, structure, age class distribution, and landscape composition) (Fig. 4a), and an additional 33\% are focused on reducing pressures on the forest landscape (e.g., forest fragmentation/ removal, wetland damage/removal, and road construction). The remaining $3 \%$ of preventative measures are focused on reducing the introduction of invasive species. Of the mitigative measures for reducing impacts on biodiversity, $43 \%$ are focused on reducing species loss caused by habitat reduction, with the remaining $57 \%$ focused on addressing decreased for- est productivity, decreased decomposition, and changes to nutrient and energy cycling (Fig. 4b).

The preventative measures are about equally legislated $(58 \%)$ and non-legislated (42\%) (Fig. 4c). In contrast, the mitigative measures aimed at reducing impacts to biodiversity after harvesting operations, such as careful road decommissioning to minimize habitat losses, are $72 \%$ legislated and $28 \%$ non-legislated.

Most (81\%) of preventive measures are hard controls of avoid (28\%) and prevent (53\%), whereas 19\% are soft controls enabling (14\%), facilitating (4\%), and tracking (1\%) the hard controls. Similarly, most of the mitigative measures (e.g., habitat alterations) are hard controls (90\%), with the remaining $10 \%$ soft controls.

Like the system of management measures for water protection, Acts and regulations comprised $70 \%$ of the preventative measures for biodiversity, with the remaining 30\% comprised of guides, manuals, BMPs, and certification standards. For mitigative measures, Acts and regulations comprised $49 \%$, with the remaining $51 \%$ comprised of guides, manuals, BMPs, certification standards. Twenty-four percent of the 
preventive measures are at the federal level, $68 \%$ are at the provincial level, and $8 \%$ are from forest certification. There is a similar distribution among mitigative measures, with $22 \%$ at the federal level, $65 \%$ at the provincial level, and $13 \%$ from certification. Almost all the non-legislated measures are from provincial sources, with $3 \%$ from certification sources.

\section{Discussion}

\section{Insights gained through testing the Bowtie}

The sustainable forest management system is complex. Our application of the Bowtie to a single sector (forestry), in a single jurisdiction (Ontario), mapped over 700 management measures related to the conservation of water quality and biodiversity. A robust system of management measures is in place to meet regulatory and certification requirements for sustaining water quality and biodiversity on managed boreal forest landscapes in Ontario.

There is a strong emphasis in the management system on prevention of pressures, with about $75 \%$ of all measures being preventative. There is an emphasis on legislated measures. The fact that most of these measures arise from provincial government requirements or guidelines is appropriate because of the provincial and territorial responsibility for forest management in Canada. Inclusion of non-legislated measures represents a policy instrument for increasing the role of society and third-party organizations (e.g., non-governmental organizations) in environmental management (Jordan et al. 2003; Eden and Bear 2010). However, there is a risk that forest management regulation strongly influenced by nongovernmental organizations could inherently reflect positions of those bodies rather than providing regulation through science-based policies and democratic legislative processes.

There is also an emphasis on hard controls that are actions preventing or reducing pressures leading to the occurrence of a risk event (Creed et al. 2016a), with over $75 \%$ of the preventative measures and $90 \%$ of the mitigative measures hard controls. Inclusion of soft controls, which are measures designed to enable, facilitate, or track the hard controls, are important in improving the performance of the management system. Soft controls may also be implemented through consultation, education, reporting, and third-party audit requirements.

Our initial scan of management measures from legislated, non-legislated, and forest management planning sources found 2259 separate management measures for water and biodiversity before we excluded older codes that were no longer relevant and redacted, or consolidated current codes where appropriate. We found that many of the on-the-ground preventive and mitigative measures (usually guidelines and BMPs) had some redundancy in that they were very closely related in their application. For example, preventive measures for biodiversity habitat loss included wildlife tree retention, but the actual directions for tree retention listed as separate measures in our analysis were essentially sub-unit instructions for the same measure (i.e., the direction to "stub some wildlife trees..." but "do not stub trees that are seed sources" or "do not stub trees better suited for other wildlife functions such as mast trees") (Ontario Ministry of Natural Resources 2010). These are all essentially elements of a single biodiversity-oriented management measure. Functional relationships among multiple values and nested measures could be further explored through linking multiple bowties together.

\section{Limitations in our current use of the Bowties}

Sustainable forest management in Ontario is based on the paradigm of adaptive management (Ontario Ministry of Natural Resources 2009) which involves: developing management measures based on science; monitoring conformance and compliance to confirm that management measures are being appropriately implemented; monitoring effectiveness to ensure that the management measures are producing the desired results; and, if necessary, adapting the management system to improve performance.

Our Bowtie analysis considered "potential performance" of the management system. The system of management measures was based on the best available science. Compliance of the management measures to standards, guidelines, BMPs and certification criteria is confirmed through provincial and certification audits (e.g., Ontario Ministry of Natural Resources 2014b; Ontario Ministry of Natural Resources and Forestry 2017; Canadian Council of Forest Ministers 2017).

However, we were not able to assess the effectiveness of the management measures. Effectiveness of management systems is often inferred from experimental studies in a single geographic setting. Therefore, while the system of management measures was based on the best available science, this does not necessarily mean that the policy objective of ecosystem sustainability was met upon their implementation, as the best available science must be relevant to the scale, geographic setting, and management issues of interest (Buttle et al. 1999, 2005, 2009).

Our Bowtie analysis did not address escalating (or deescalating) factors (e.g., Seidl et al. 2017). Therefore, even if implementation of the system of management measures meant that sustainability objectives were currently being met, this does not mean that they will continue to be met in the near future. Increased ecosystem complexity and uncertainty will exist due to the effects of climate change and atmospheric pollution as well as other stressors including the cumulative effects of other natural resource extraction activities on managed forested landscapes (Williamson et al. 2012; Edwards et al. 2015; Messier et al. 2016). Existing measures of effectiveness-such as staying within the range of natural variationmay no longer be relevant. There may be a need to change the policy target itself under a "new normal" (Sauchyn et al. 2010; Williamson and Edwards 2014) or to adopt the notion of "novel ecosystems" as a desirable outcome (e.g., Audet et al. 2015). Government agencies and certification bodies are seeking rigorous means to assess the effectiveness of their system of management measures in the face of this uncertainty and complexity, and tools are required that can accommodate these assessments in a dynamic and timely manner.

\section{Future steps}

We need to extend the current work in the following ways to improve the utility of the Bowtie approach to managing risk of failure to achieve sustainability of the boreal zone.

First, all the information utilized was publically available but came from highly technical and specialized documents and plans. An interdisciplinary team approach (science, strategic plans, technical operations, policy) was required to obtain the maximum benefit from the available information. Going forward, we require further discussion of our results and their validation by experts in policy and industry imple- 
mentation. The Bowtie can provide the common and objective language that is needed to facilitate discourse and navigation of the science-policy interface.

Second, our inventory of pressures and impacts and the management system was specific for the boreal forest in Ontario. Going forward, we require similar information for other regions of the boreal forest, and Canada's managed forests more broadly.

Third, our analysis was restricted to characterizing the management system, but not evaluating its performance, which requires information on both the compliance or adoption and effectiveness of each measure in the management system. Going forward, we need to shift towards a more quantitative analysis of both the pressure-effects-impacts risk pathways and the performance of the management system to reduce risk events. Where empirical data or models exist, there is the opportunity to couple the performance of the system of management measures with the pressures-effectsimpact risk pathway. In other words, we can superimpose the Bowtie onto mechanistic (vs. empirical) models, enabling feedbacks between the ecosystem and the management system operating on the ecosystem under changing conditions. Furthermore, we can incorporate ecosystem complexity and uncertainty by combining probabilistic methods such Bayesian belief networks together with the Bowtie. In this manner, the performance of the management system can be determined quantitatively while considering compliance or adoption metrics, effectiveness metrics, and the probability of escalation factors (International Council for the Exploration of the Sea 2015). On the other hand, where empirical data or models do not exist or are incomplete, the performance of the management system can be achieved through alternative means (e.g., regionally relevant expert opinion, and local and Indigenous knowledge).

Finally, to be applicable to a cumulative effects context, we need to consider incorporation of other sustainability criteria for forests into the analysis, as well as consider other natural resource sectors that operate adjacent to, are concurrent with, and influence forest management activities. We also require scaling-up of the analysis to regional and potentially national scales.

\section{Conclusions}

The Bowtie Risk Management Assessment Tool is a valuable asset for exploring the risk of existing forest management systems of failing to achieve sustainable forest management criteria. The key benefit of the Bowtie is that it provides an objective and "level playing field" for assessing management risks. For example, the Bowtie can be used by regulatory agencies and certification bodies to provide a systematic description of their management system, including strengths vs. weaknesses and redundancies vs. gaps among their respective policies and practices. This would serve to improve understanding of the role of management measures in the prevention of risk events and the mitigation of risk impacts. Furthermore, the Bowtie can provide land managers with an understanding of their risk profile (i.e., the consolidated suite of pressures under which they are operating). Widespread adoption of the Bowtie approach would facilitate consistency in the application, interpretation, and reporting of cumulative effect from natural resource extraction activities across jurisdictions and resource sectors, with its ISO designation bringing international recognition and credibility.

\section{Acknowledgements}

The Sustainable Forestry Initiative's Central Canada SFI Implementation Committee (CCSIC) provided a helpful forum for exploration of these concepts. We acknowledge the technical contributions of Haibin (Rick) Dong, Xhuli Cui, and Jackie Serran from Western University, and Troy Anthony for ongoing feedback and Angela Lowry (CFS) for technical assistance. Maud Couture Naud and Amelie Roberge (CFS) assisted in early policy context discussion. Earlier reviews by Mike Brienesse and Aaron Kuchirka helped to improve this manuscript. We thank an anonymous journal reviewer for feedback. We acknowledge funding support received under the Canadian Forest Service's ADM Innovation Fund, Round 2.

\section{References}

Andrew, M.E., M.A. Wulder and J.A. Cardille. 2014. Protected areas in boreal Canada: A baseline and considerations for the continued development of a representative and effective reserve network. Environ. Rev. 22(2): 135-160. doi:10.1139/er-2013-0056.

Audet, P., B. Pinno and E. Thiffault. 2015. Reclamation of boreal forest after oil sands mining: Anticipating novel challenges in novel environments. Can. J. For. Res. 45(3): 364-371. doi:https://doi.org/ 10.1139/cjfr-2014-0330.

BowtieXP Software Release Version 8.2.9 2017. CGE Risk Management Solutions, Leidschendam, Netherlands.

Brandt, J.P., M.D. Flannigan, D. G. Maynard, I.D. Thompson and W.J.A Volney. 2013. An introduction to Canada's boreal zone: Ecosystem processes, health, sustainability, and environmental issues. Environ. Rev. 21(4): 207-226. doi: https://doi.org/10.1139/er 2013-0040.

Buttle, J.M., I.F Creed and J.W. Pomeroy. 1999. Advances in Canadian forest hydrology, 1995-1998. Hydrological Processes 14: 1551-1578.

Buttle, J.M., I.F. Creed and R.D. Moore. 2005. Advances in Canadian forest hydrology, 1999-2003. Hydrological Processes 19: 169-200.

Buttle, J.M., I.F. Creed and R.D. Moore. 2009. Advances in Canadian forest hydrology, 2003-2007. Canadian Water Resources Journal 34: 113-126.

Canadian Forest Service. 2005. Criteria and Indicators Framework. http://cfs.nrcan.gc.ca/publications?id=32560 [accessed 13 July 2017]. Canadian Council of Forest Ministers. 2008. Measuring our progress: Putting sustainable forest management into practice across Canada and beyond. http://www.ccfm.org/pdf/CCFM_Measuring_our_progress.pdf [accessed 25 Oct 2017].

Canadian Council of Forest Ministers. 2017. Making the case for sustainable forest management certification. http://www.sfmcanada.org/images/Publications/EN/Sustainable_Forest_Management_Certification_EN. df [accessed 13 July 2017].

Canadian Council of Ministers of the Environment. 2009. Regional Strategic Assessment in Canada: Principles and Guidance. Winnipeg, MB. http://www.ccme.ca/files/Resources/enviro_assessment/rsea_principles_guidance_e.pdf [accessed 13 July 2017].

Canadian Standards Group. 2016. CSA Z809-16 Sustainable Forest Management. http://shop.csa.ca/en/canada/sustainable-forest-management/cancsa-z809-16/invt/27017442016 [accessed 12 July 2017]. 
Certification Canada. 2017. Certification Summary. http://certificationcanada.org/wp content/uploads/2017/03/2016-Yearend-SFMCertification_Summary-Report-Final-170303.pdf.[accessed 29 May 2017].

CGE Risk. 2015. Bow Tie XP Software Manual for BowTieXP 7.0. Leidschendam, The Netherlands.

Chartrand, L. 2016. Enquête sur une bataille de titans au pays des caribous. http://ici.radio canada.ca/tele/enquete/2015-2016/episodes/ 362452/enquete-foret-boreale-greenpeace-resolu-caribou forestier?is AutoPlay $=1$ [accessed 12 July 2017].

Clark, M.R. and J.S. Kozar. 2011. Comparing sustainable forest management certifications standards: A meta-analysis [online]. Ecol. Soc. 16(1):3. Available from: http://www.ecologyandsociety. org/vol16/iss1/art3 [accessed 13 July 2017].

Cormier, R., A. Kannen, M. Elliott, P. Hall, and I.M. Davies. (eds.) 2013. Marine and coastal ecosystem-based risk management handbook. International Council for the Exploration of the Sea (ICES). ICES Research Report no. 317. https://www.ices.dk/sites/pub/ Publication\%20Reports/Cooperative\%20Research\%20Report\%20 (CRR)/crr317/CRR317\%20Marine\%20and\%20coastal\%20ecosystem $\% 20$ based\%20risk\%20management\%20handbook.pdf [accessed 13 July 2017].

Creed, I.F. et al. 2016a. Formal integration of science and management systems needed to achieve a thriving and prosperous Great Lakes. Bioscience 66 (5): 408 418. doi: https://doi.org/10.1093/ biosci/biw030.

Creed, I.F., M. Weber, F. Accatino and D.P Kreutzweiser. 2016b. Management forests for water in the anthropocene - the best kept secret services of forest ecosystems. Forests 7(3): 60. doi:10.3390/ f7030060.

Eden, S. and C. Bear. 2010. Third sector global environmental governance, space and science: Comparing fishery and forestry certification. J. Environ. Pol. Plan. 12(1): 83-106. doi: http://dx.doi.org/ $10.1080 / 15239081003626000$.

Edwards, J.E., C. Pearce, A.E. Ogden and T.B. Williamson. 2015. Climate change and sustainable forest management in Canada: A guidebook for assessing vulnerability and mainstreaming adaptation into decision-making. Canadian Council of Forest Ministers. Ottawa, Ontario. http://www.ccfm.org/pdf/Vulnerability\%20Guidebook_June2_EN.pdf [accessed 13 July 2017].

Forest Stewardship Council. 2016. Canada National Forest Management Standard: Draft 2. 2016. https://ca.fsc.org/en-ca/ourwork/forest-management-standard-revision-01. (DRAFT 2 Consultation period: November 24, 2016 to February 17, 2017) [accessed 13 July 2017].

Gauthier, S., P. Bernier, P.J. Burton, J. Edwards, K. Isaac, N. Isabel, K. Jayen, H. Le Goff and E. Nelson. 2014. Climate change vulnerability and adaptation in the managed Canadian boreal forest. Environ. Rev. 22(3): 256-285. doi:10.1139/er-2013-0064.

International Council for the Exploration of the Sea. 2015. Report of the Workshop on Probabilistic Assessments for Spatial Management, 9-13 March 2015, Hamburg, Germany.

IEC/ISO. 2009. [International Electrotechnical Commission/ International Organization for Standardization]. IEC/ISO 31010. 2009. Risk Assessment Techniques. http://www.iso.org/iso/catalogue_detail?csnumber $=51073$ [accessed 10 December 2015].

ISO. 2009. [International Organization for Standardization. ISO 31000.] Risk Management - Principles and Guidelines. http://www. iso.org/iso/catalogue_detail?csnumber $=43170$ [accessed 30 November 2015].

International Organization for Standardization. 2015. ISO 14001 - Environmental Management Systems Standard 2015. https://www. iso.org/obp/ui/\#iso:std:iso:14001:ed-3:v1:en. [accessed 29 May 2017].
Jordan, A., R.K.W Wurzel and A.R. Zito. 2003. "New" environmental policy instruments: An evolution or revolution in environmental policy? Env. Polit. 12(1): 1-24. doi: ttp://dx.doi.org/ 10.1080/714000667.

Kreutzweiser, D., F. Beall, K. Webster, D. Thompson and I.F. Creed. 2013. Impacts and prognosis of natural resource development on aquatic biodiversity in Canada's boreal zone. Environ. Rev. 21(4): 227-259. doi: https://doi.org/10.1139/er-2013-0044.

Kuitenbrouwer, P. and P.J. Thompson. 2016. Battle for the Boreal. Financial Post. http://business.financialpost.com/features/battle-forthe-boreal-forest-2 [accessed 12 July 2017].

Kurz, W.A., C.H. Shaw, C. Boisvenue, G. Stinson, J. Metsaranta, D. Leckie, A. Dyk, C. Smyth and E.T. Neilson. 2013. Carbon in Canada's boreal forest - A synthesis. Environ. Rev. 21(4): 260-292.

Langor, D.W. et al. 2014. Non-native species in Canada's boreal zone: Diversity, impacts and risk. Environ. Rev. 22(4): 372-420. doi: https://doi.org/10.1139/er-2013-0041

Lemprière, T.C. et al. 2013. Canadian boreal forests and climate change mitigation. Environ. Rev. 21(4): 293-321. doi: https:// doi.org/10.1139/er-2013 0039.

Maynard, D.G., D. Pare, E. Thiffault, B. Lafleur, K.E. Hogg and B. Kishchuk. 2014. How do natural disturbances and human activities affect soils and tree nutrition and growth in the Canadian boreal forest? Environ. Rev. 22 (2): 161-178. doi: https://doi.org/10.1139/er2013-0057.

Messier, C., K. Puettmann, E. Filotas and D. Coates. 2016. Dealing with non-linearity and uncertainty in forest management. Current Forestry Reports 2: 150-161. doi: 10.1007/s40725-016-0036-x.

Moas, A. 2014. Best Buy Is Wasting Ancient Forests, One Flyer at a Time [online]. Available from http://www.greenpeace.org/usa/ bestbuy/ [accessed: 12 July 2017].

Montréal Process. 2015. Criteria and Indicators for the Conservation and Sustainable Management of Temperate and Boreal Forests. Fifth Edition, September 2015. https://www.montrealprocess.org/ documents/publications/techreports/MontrealProcessSeptember 2015.pdf [accessed 22 July 2017].

Moore, S.E., F. Cubbage and C. Eicheldinger. 2012. Impacts of Forest Stewardship Council (FSC) and Sustainable Forestry Initiative (SFI) forest certification in North America. J. For. 110(2): 79-88. doi: https://doi.org/10.5849/jof.10-050.

National Council for Air and Stream Improvement. 2014. Compilation of Canadian provincial and federal regulations relevant to forest management activities. http://www.ncasi.org/Programs/ Forestry/Resources/Compilation-of-Canadian-Regulations/ Index.aspx [accessed 13 July 2017].

Natural Resources Canada. 2016. Sustainable Forest Management in Canada. http://www.nrcan.gc.ca/forests/canada/sustainable-forest-management/13183 [accessed 14 July 2017].

Natural Resources Canada. 2017. The State of Canada's Forests: Annual Report. Ottawa, ON. http://cfs.nrcan.gc.ca/publications? id=38871. [accessed 25 October 2017].

Ontario Ministry of Natural Resources. 1994. Crown Forest Sustainability Act. Statutes of Ontario. Chapter 25. https://www. ontario.ca/laws/statute/94c25/v6 [accessed 22 March 2017].

Ontario Ministry of Natural Resources. 2009. Forest Management Planning Manual for Ontario's Crown Forests. Toronto: Queen's Printer for Ontario. http://files.ontario.ca/environment-andenergy/aggregates/provincial-standards/stdprod_100221.pdf

Ontario Ministry of Natural Resources. 2010. Stand and Site Scales Guide: Forest management guide for conserving biodiversity at the stand and site scales. Toronto, ON. https://www.ontario.ca/document/forest-management-conserving-biodiversity-stand-and-sitescales [accessed 13 July 2017]. 
Ontario Ministry of Natural Resources. 2014a. Boreal Landscapes: Forest Management Guide for Boreal Landscapes. Queen's Printer for Ontario. https://dr6j45jk9xcmk.cloudfront.net/documents/ 2783/guide-boreal-landscape-aoda.pdf [accessed 13 July 2017].

Ontario Ministry of Natural Resources. 2014b. Independent Forest Audit Process and Protocol 2015. https://dr6j45jk9xcmk.cloudfront.net/documents/3971/ifapp-2015-2014-11-30-aoda.pdf [accessed 31 May 2017].

Ontario Ministry of Natural Resources and Forestry. 2015. Forest Management Guide to Silviculture in the Great Lakes-St. Lawrence and Boreal Forests of Ontario. https://dr6j45jk9xcmk. cloudfront.net/documents/4125/revised-silvguide-mar-2015-aodacompliant.pdf [accessed 13 July 2017].

Ontario Ministry of Natural Resources and Forestry. 2017. Independent Forest Audits. https://www.ontario.ca/page/independentforest-audits [accessed 31 May 2017].

Price, D.T. et al. 2013. Anticipating the consequences of climate change for Canada's boreal forest ecosystems. Environ. Rev. 21(4): 322-365. doi: https://doi.org/10.1139/er-2013-0042

Rotherham, T. 2016. Forest management certification in Canada and around the world. For. Chron. 92(2): 142-146. doi: https://doi.org/10.5558/tfc2016-031

Sauchyn, D., H. Diaz and S. Kulshreshtha. 2010. The new normal: The Canadian Prairies in a Changing Climate. Canadian Plains Research Center; First Edition, University of Regina Press.

Seidl, R. et al. 2017. Forest disturbances under climate change. Nature Climate Change 7: 395-402. doi: https://DOI:10.1038/nclimate3303. Published online 31 May 2017

Stelzenmüller, V. et al. 2018. A risk-based approach to cumulative effects assessments for marine management. Science of the Total Environment. 612 (2018) 1132-1140. Available online: http: //dx.doi.org/10.1016j.scitotenv.2017.08.289.

Sustainable Forestry Initiative. 2015. SFI 2015-2019 Standards and Rules. Forest Management Standard. http://www.sfiprogram.org/ files/pdf/2015-2019-standardsandrules-web-lr-pdf/ [accessed 1 January 2017].
Venier, L.A. et al. 2014. Effects of natural resource development on the terrestrial biodiversity of Canadian boreal forests. Environ. Rev. 22(4): 457-490. doi: https://doi.org/10.1139/er 2013-0075.

Webster, K.L., F.D. Beall, I.F. Creed and D.P. Kreutzweiser. 2015. Impacts and prognosis of natural resources development on water and wetlands in Canada's boreal zone. Environ. Rev. 23(1): 78-131.doi: 10.1139/er-2013-0044. doi: https://doi.org/10.1139/er2014-0063.

Williamson, T., and Edwards, J. 2014. Adapting sustainable forest management to climate change: Criteria and Indicators in a changing climate. Canadian Council of Forest Ministers. Ottawa, Ontario. http://www.ccfm.org/pdf/CriteriaIndicatorsENG_DigitalF.pdf [accessed 13 July 2017]

Williamson, T., M. A. Campagna and A.E. Ogden. 2012. Adapting sustainable forest management to climate change: A framework for assessing vulnerability and mainstreaming adaptation into decisionmaking. Canadian Council of Forest Ministers: Ottawa, Ontario. http://www.ccfm.org/pdf/Vulnerability\%20Guidebook_June2_EN. pdf [accessed 13 July 2017].

\section{List of Supplementary Information}

Supplementary Information 1: Forest management pressures and impacts on water quality

Supplementary Information 2: Forest management pressures and impacts on biodiversity

Supplementary Information 3: Names and implementation dates of measures for water quality

Supplementary Information 4: Names and implementation dates of management measures for biodiversity. 